
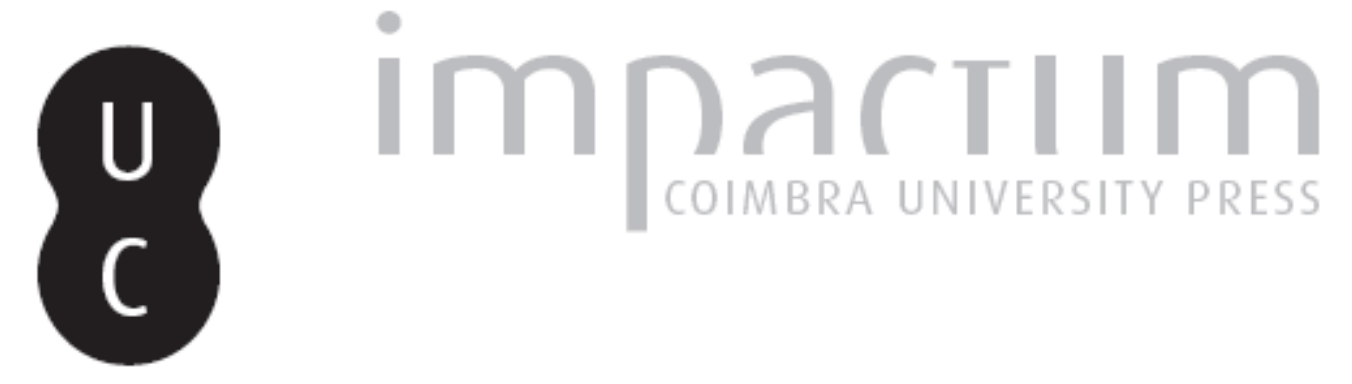
A Neolithic skull lesion probably caused by an arrowhead
Autor(es): $\quad$ Silva, Ana Maria
Publicado por: CIAS - Centro de Investigação em Antropologia e Saúde
URL persistente:
URI:http://hdl.handle.net/10316.2/41267
DOI:
DOI:http://dx.doi.org/10.14195/2182-7982_19_11
Accessed : $\quad$ 26-Apr-2023 10:12:23

A navegação consulta e descarregamento dos títulos inseridos nas Bibliotecas Digitais UC Digitalis, UC Pombalina e UC Impactum, pressupõem a aceitação plena e sem reservas dos Termos e Condições de Uso destas Bibliotecas Digitais, disponíveis em https://digitalis.uc.pt/pt-pt/termos.

Conforme exposto nos referidos Termos e Condições de Uso, o descarregamento de títulos de acesso restrito requer uma licença válida de autorização devendo o utilizador aceder ao(s) documento(s) a partir de um endereço de IP da instituição detentora da supramencionada licença.

Ao utilizador é apenas permitido o descarregamento para uso pessoal, pelo que o emprego do(s) título(s) descarregado(s) para outro fim, designadamente comercial, carece de autorização do respetivo autor ou editor da obra.

Na medida em que todas as obras da UC Digitalis se encontram protegidas pelo Código do Direito de Autor e Direitos Conexos e demais legislação aplicável, toda a cópia, parcial ou total, deste documento, nos casos em que é legalmente admitida, deverá conter ou fazer-se acompanhar por este aviso.

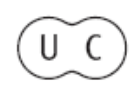


Antropologia Portuguesa

Volume $19 \cdot 2002$

Departamento de Antropologia | Universidade de Coimbra 


\title{
A Neolithic skull lesion probably caused by an arrowhead
}

\author{
Ana Maria Silva \\ Departamento de Antropologia \\ Universidade de Coimbra \\ 3000 - 056 Coimbra, Portugal \\ amgsilva@ci.uc.pt
}

Abstract An incomplete frontal bone exhumed from the collective burial of Dólmen de Ansiāo (district of Leiria, Portugal) dated to the end of the Neolithic, presented on his left side, behind the orbit, a healed injury. No signs of infection or any kind of complication are visible. A possible diagnosis for this lesion is a trauma caused by an arrowhead which, if confirmed, would be the first one reported for a prehistoric Portuguese site.

Key words Skull injury; collective burial; late Neolithic; Dólmen de Ansião; Portugal.

Resumo Um frontal esquerdo incompleto recuperado do Dólmen de Ansião (distrito de Leiria, Portugal), uma sepultura colectiva do Neolítico Final, apresenta uma lesão remodelada, localizada entre a bossa frontal e a crista lateral. Não são visiveis quaisquer sinais de infecção ou outro tipo de sequelas. Como possivel diagnóstico sugerimos um trauma produzido por uma ponta de seta e, em caso de confirmação, seria o primeiro descrito para séries pré-históricas Portuguesas.

Palavras-chave Trauma craniano; sepultura colectiva; Dólmen de Ansiāo, Neolítico Final; Portugal. 


\section{Introduction}

The Dólmen de Ansião (district of Leiria) was discovered in the end of the $19^{\text {th }}$ century during the construction of the road between Ansião and Coimbra, in a mountainous area. Unfortunately, no report of the discovery of this archaeological site is known. The available records indicate that in 1968, the Dólmen was already destroyed (Leisner, 1998).

In the first half of the last century the human bones and some archaeological artefacts were transferred to the Museu Antropológico of the University of Coimbra, were they are stored to this day. In 1997, the anthropological study of these human remains was initiated (Silva, 2002).

In this collective burial the remains of a minimum of 37 individuals have been identified, 23 adults (of both sexes) and 14 non-adults (all age groups are represented). Because the burials were disturbed, the relationship between skeletal elements could not be determined (Silva, 2002). The standard radiometric dating performed on a femur fragment gave a data range between 3637 3094 cal BC (2 sigma), 3610 - 3339 cal BC (1 sigma) or $4640 \pm 90$ BP (Sac - 1559), confirming a Late Neolithic Age.

In these human remains, only cranial injuries were detected. These include five depressed fractures of the skull vault, two located on frontal bones, two above the sagittal suture and one on the occipital bone. All lesions, detected in adult bones, are completely healed, indicating long-term survival after the injury. The exact frequencies of these wounds are difficult to establish since some fragments could belong to the same individual. Only for the frontal bones it is possible to present the prevalence of $9,5 \%$ $(2 / 21)$. The most likely cause of these lesions is falls of these individuals during their daily activities in a mountain region, although the hypothesis of interviolence episodes can't be excluded.

In the cranial bones, besides these fractures, one frontal bone displays a different injury that is the object of this study. 


\section{Description of the case}

The frontal bone belongs to an adult individual, whose sex was impossible to determine (Ferembach et al., 1980). Behind the left orbit, a triangular lesion occurs (Figures 1A and 1B). On the lateral side of the bone, a postmortem fracture led to the loss of some bone, making it impossible to determine all the measurements associated with the injury (Figure 1B). The estimated maximum exocranial dimension of the lesion is $30 \mathrm{~mm}$ by $15 \mathrm{~mm}$. On the tip of the lesion there was a complete perforation of both tables of the bone. This roughly ellipsoid opening measured approximately $5 \mathrm{~mm}$ by $2.5 \mathrm{~mm}$. Signs of healing are visible in the external and internal surfaces, including in the margins of the hole.

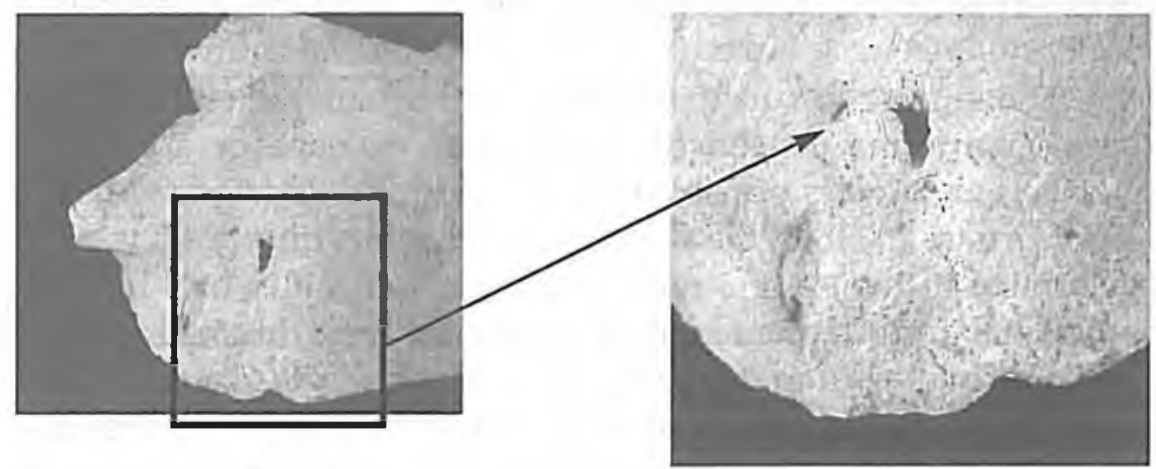

A

B

Figure 1. A. Exocranial view of the left side of the frontal bone (DEA. 843) exhumed from the Dólmen de Ansiăo showing the injury interpreted as caused by an arrowhead; B. Detail of the lesion (exocranial view).

Figure 2. Endocranial view of the injury. Note the complete perforation of the bone and the fused bone mass $(\rightarrow)$.

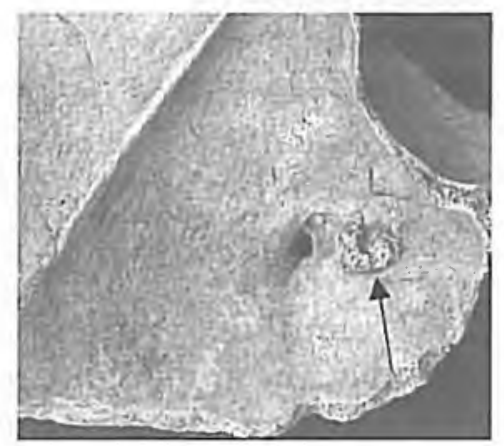


In the endocranial view (Figure 2), the smooth margins of the defect are even more proeminent. Lateral to the hole there is a small, roughly circular bone mass, probably associated with the traumatic event, that is fused with the inner table of the frontal bone. Around the lesion there are no signs of infection or other complication.

\section{Interpretation}

The described trauma seems to result from the impact of a projectile, possibly an arrowhead. However other weapons cannot be excluded. The weapon would have struck the adult individual from left and behind, with its tip completely perforating the cranial bone.

The distinction in archaeological human skeletal remains between trauma caused by intentional violence or accidental events is not always possible (Aufderheide and Rodríguez-Martín, 1998; Ortner, 2003). In the present case, the data do not allow us to determine if this trauma resulted from a war injury or a hunting accident. No signs of intentional aggression were detected in other bones recovered from this collective burial place. Furthermore, the fact that these people lived in a mountain region, where falls would be frequent during their everyday activities, are facts in favour of accidental events.

\section{Final comments}

The injury described on an adult frontal bone exhumed from the Dólmen de Ansião seems to be caused by an arrowhead. Although some causes can be excluded such as trepanation others like a skull fracture, of crushing type remain possible although a penetrating wound from a projectile is most likely.

According to Armendariz et al. (1994) only five prehistoric sites have been identified in the Iberian Peninsula, all in Spain, with reliable evidence of wounds made by arrowheads, Hipogeum 
de Longar (four cases, Armendariz et al., 1994), Dólmen de Collet Su (one case, Campillo, 1977), Cova de l'Heure (one case, Campillo, 1983), San Juan ante Portem Latinam (nine cases, Etxeberria and Vegas, 1992), and San Quirce del Valles (one case, Campillo et al, 1993) representing 16 cases, besides other doubtful cases that have been mentioned (Armendariz ot al., 1994: Campillo ct al., 1983). These injuries were found in individuals of both sexes and include wounds with signs of healing (as the case now reported) and others that are characterized by a lack of healing that indicates violent death of the individuals at the time of the trauma (Armendariz et al. 1994). Yet, none of these have the same location in the skull as the one here presented: they include cases in other cranial bones, ribs, vertebrae and in the superior portion of the humerus. The case of the Dólmen de Ansião presented in this report provides early evidence of a possible arrow wound that would be the first one identified in a Prehistoric Portuguese site.

\section{Acknowledgments}

Instituto Ambiente e Vida; Maria Teresa Ferreira, Eugénia Cunha, Sónia Codinha (Departamento de Antropologia, Universidade de Coimbra). Francisco Etxeberria, Donald Ortner, Miguel Botella and the anonymous reviewers.

\section{Bibliography}

Armendariz, J.; Irigarai, S.; Etxeberria, F. 1994. New evidence of Prehistoric arrow wounds in the Iberian Peninsula. International Jourmal of Osteonrchneology, 4 (3): 215-222.

Aufderheide, A. C.; Rodriguez-Martín, C. 1998. The Cambridge Encyclopedia of Human Paleopathology. Cambridge, Cambridge University Press.

Campillo, D. 1977. Paleopatologín del cráneo. En Cataluña, Valencia y Baleares. Barcelona, Editorial Montblanc-Martín. (Colección de Monografías Locales; Serie B. 17). 
Campillo, D. 1983. La enfermedad en In Prehistorin. Barcelona, Salvat.

Campillo, D.; Mercadal, O.; Blanch, R.-M. 1993. A mortal wound caused by a flint arrowhead in individual MF-18 of the Neolithic Period exhumed at Sant Quirze del Valles. International Journal Osteonrcheology, 3(2): 145-150.

Etxeberria, F; Vegas, J. 1992. Heridas por flecha durante la Prelistoria en la Península Ibérica. Munibe, 8 (Supl.): 129-136.

Ferembach, D.; Schwidetzky, I.; Stloukal, M. 1980. Recomendations for age and sex diagnosis of skeletons. Joumal of Human Evolution, 9(7): 517-549.

Leisner, V. 1998. Die Megalithgraeber der Iberischen Halbinseln. Der Western. Madrider Forschungen, 1/4. Berlin, Walter de Gruyter \& C.

Ortner, D. 2003. Identification of pathological conditions in human skeletal remnins. $2^{\text {nd }}$ edition. San Diego, Academic Press.

Silva, A. M. 2002. Paleobiologin das populaçōes Portuguesas (litornis) do Neolitico final $\mathcal{C}$ Calcolítico. Dissertação de Doutoramento em Antropologia Biológica, Departamento de Antropologia, Universidade de Coimbra. 